I shall be eternally grateful to the editors for not burdening us with countless sets of geographic coordinates. But they could have located places and features somewhat more precisely than identifying their towns (i.e. townships) and their USGS maps.

Since this is a dictionary one isn't expected to read it from cover to cover. And dictionaries, as we know, are terribly expensive to produce. Thus editors are probably justified in sacrificing clarity for comprehensiveness by using abbreviations. This does reduce a book's size somewhat. But it does make it more difficult to use when readers have to frequently refer to the "explanatory notes," since they are apt to forget to what the abbreviations refer.

These demurrals aside, I really liked this book. It is one of the few books I have on New York placenames and I hope it won't be the last. With the few suggestions mentioned above it could become a model for other New York State county place names books and, ultimately, the comprehensive New York State volume. Professor Harder is certainly the person to see these through, and I hope I will be called upon to review more of them.

Robert M. Rennick Prestonsburg, KY

\title{
Western States Meeting
}

The 1994 meeting of the Western States Geographic Names Council will be held in the Black Hills, in Rapid City, South Dakota, September 7-10. Abstracts for papers on aspects of names and naming in the Western States and Provinces are invited. For further information, write to the coordinator:

\author{
Professor Thomas J. Gasque \\ Department of English \\ The University of South Dakota \\ Vermillion SD 57069
}




\section{Recent Transferred and Figurative Uses of Chicago}

In 'Tingo María's Child Addicts: In Peru, plenty of drugs, but not enough to eat" (Newsweek, 31 March 1986, p. 32), Alma Guillermo-prieto mentions Chicago Chico 'Little Chicago,' a druginfested, low-income neighborhood of Tingo María, a town in Peru.

In "In Tense French Town, the Melting Pot Boils Over" (The New York Times, 3 September 1986, p. A2), Richard Bernstein writes of "a particularly rundown district behind the port [of Toulon] known, with no compliment intended, as Chicago."

From Celestine Bohlen ("In Sovereign Georgia, Crime, Civil War and Empty Coffers," The New York Times, 21 August 1993, pp. Al and $A 14$ ) we learn that "the sound of gunfire is so frequent in one Tblisi neighborhood that its residents now call it Chicago" (p. Al).

All of those usages allude to the crime-infested Chicago of the Capone Era. If the city became notorious in such distant countries as Peru, France, and Georgia, it is not surprising that we find similar figurative usages in English too: Chicago 'pineapple sundae; pineapple soda' (an allusion to Chicago pineapple 'small grenade; small bomb'), Chicago overcoat 'coffin,' and Chicago piano or Chicago typewriter 'Thompson submachine gun.'

Yet Chicago is not always used negatively. After the Columbian Exhibition opened in Chicago (in 1893), chicago came to mean 'merry-go-round' in Chilean Spanish. It was at that exhibition that George W.G. Ferris introduced his Ferris wheel, but Chileans confused it with the merry-go-round and thus applied the American place name to something with which neither Ferris nor the fair was particularly associated (the merry-go-round being no younger than 1729).

Other positive usages are English Chicago cut or Chicago steak 'strip steak, shell steak,' Chicago flats 'heelless shoes made of a piece of leather shaped to the sole' (also called St. Louis flats), and Chicago window (a kind of window first used in commercial buildings in Chicago in the 1880s). 


\section{The 1993 Western Geographic Names Conference}

The 17th Western Geographic Names Conference was held in El Paso, Texas, 8-11 September 1993, with Lurline Coltharp presiding. This was the first meeting of the conference which included scholarly papers on geographic names and the first which included substantial participation by the American Name Society. Both the Conference and the Society hope that this cooperation will continue, and in the future will provide a forum where geographers, historians and onomasticians may meet with colleagues in government, academia and private sectors. The American Name Society participants included Lewis L. McArthur, the current president, and well as seven past presidents: Lurline Coltharp, Sarah Jackson, Mary Miller, Don Orth, Roger Payne, Alan Rayburn and Fred Tarpley. Wayne Finke, Executive Secretary, also participated.

The conference included two meetings of the Place Name Survey of the United States (PLANSUS), chaired by Grant Smith, as well as a most interesting toponymic tour of the Rio Grande Valley.

Lewis L McArthur

\section{New Bibliography of the Coltharp Collection}

The updated (through August 1993) Bibliography of the Lurline $\mathrm{H}$. Coltharp Collection of Onomastics is now available. Compiled by Roberta Arney, the Onomastics Bibliography now extends to 74 pages. For information on the Coltharp Collection or the Bibliography, write or call the Onomastics Collection at the University of Texas at EI Paso Library, EI Paso, TX 79968. Telephone: 915-7475643. 


\section{Special Issue of Names}

The December 1993 issue of Names will be a Festschrift honoring Leonard R. N. Ashley for his years of service to the American Name Society and his many contributions to the study of names and naming. The issue will be delayed until early in 1994, so there is time to revise convention papers and complete works in progress for this special issue. Contributors should send completed manuscripts to the Editor by 30 January 1994. In keeping with the eclectic nature of Len Ashley's onomastic mind, papers on any or all aspects of names and naming would be appropriate. All manuscripts will undergo the normal Names review process and they should be prepared according to the guidelines found on the inside back cover. Send manuscripts specifying that they are for the Ashley issue - or requests for further information to:

Edward Callary, Editor, Names

English Department, Northern Illinois University

DeKalb, II 60115 